Article

\title{
The Fermentation Process Improves the Nutritional Value of Rapeseed Cake for Turkeys-Effects on Performance, Gut Bacterial Population and Its Fermentative Activity
}

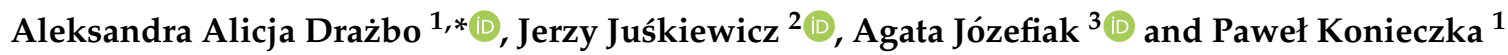 \\ 1 Department of Poultry Science, Faculty of Animal Bioengineering, University of Warmia and Mazury in \\ Olsztyn, Oczapowskiego 5, 10-719 Olsztyn, Poland; pawel.konieczka@uwm.edu.pl \\ 2 Institute of Animal Reproduction and Food Research of the Polish Academy of Sciences, Tuwima 10, \\ 10-748 Olsztyn, Poland; j.juskiewicz@pan.olsztyn.pl \\ 3 Department of Preclinical Sciences and Infectious Diseases, Poznan University of Life Sciences, Wolynska 35, \\ 60-637 Poznan, Poland; agata.jozefiak@up.poznan.pl \\ * Correspondence: aleksandra.drazbo@uwm.edu.pl
}

Received: 11 August 2020; Accepted: 19 September 2020; Published: 22 September 2020

check for updates

Simple Summary: Rapeseed cake (RC) could be valuable raw material in turkey diets, but its wide use is limited by the presence of anti-nutritional factors that are detrimental to gut function. The fermentation process contributes to the degradation of over $80 \%$ of carbohydrates, $30 \%$ of lignin, and $45 \%$ of total glucosinolates in RC, which are harmful to birds. Our research showed that fermentation can improve the nutritional value of $\mathrm{RC}$, enabling good performance and maintainenance of a healthy gut in birds. Therefore, FRC appears to be highly promising in commercial turkey nutrition.

Abstract: This experiment investigated the potential inclusion of fermented rapeseed cake (FRC) in turkey diets. The turkeys received diets either not supplemented (C) or supplemented with raw rapeseed cake (RRC) or FRC at $150 \mathrm{~g} / \mathrm{kg}$ diet. In comparison with RRC, turkeys receiving FRC achieved significantly higher final BW comparable with that noted in the control group. The dietary inclusion of FRC increased the concentrations of propionic and valeric acid in the cecal digesta compared with the control group, and increased the proportion of butyric acid in SCFA profile compared with RRC group. The activities of glycolytic bacterial enzymes in the cecal digesta, were lowest in turkeys fed FRC. Experimental diets did not cause a shift in the relative abundances of the main bacterial phyla or orders in the cecal digesta. FRC increased the abundance of Bacteroidaceae at the family level, but decreased the abundance of Lactobacillus at the genus level compared with birds fed RRC. In conclusion, the dietary inclusion of FRC at $150 \mathrm{~g} / \mathrm{kg}$ did not compromise bird performance, did not excessively stimulate bacterial activity, and did not cause shifts in the bacterial composition in the cecum. Actually, FCR exerted several beneficial effects that contributed to maintaining gut health in turkeys, which points to its advantage over RRC.

Keywords: gastrointestinal tract; microbiome; turkey; rapeseed cake; fermentation

\section{Introduction}

Rapeseed cake (RC), a by-product of oil production, could be a valuable component of poultry diets because it contains up to $400 \mathrm{~g} / \mathrm{kg}$ crude protein (CP) and high concentrations of metabolizable energy $[1,2]$. Unfortunately, wide use of $\mathrm{RC}$ is limited by the presence of non-starch polysaccharides (NSP) and other anti-nutritional factors such as glucosinolates, phytic acid, sinapine, and tannins [3]. 
High NSP levels in poultry diets may stimulate the proliferation and activity of gut microbiota [4], and increase the viscosity of small intestinal digesta, thus impairing the rate of food passage and nutrient utilization [3]. Glucosinolates hydrolyzed by the enzyme myrosinase are the most toxic compounds in rapeseed, and their maximum level in animal feed should not exceed $2.5 \mu \mathrm{mol} / \mathrm{g}$ [5]. Previous studies indicate that the impact of rapeseed products, rich not only in NSP, lignin and polyphenols but also in glucosinolates, may be more pronounced in turkeys than in broiler chickens due to a much longer fattening period in the former [4]. According to many authors, the inclusion rates of rapeseed products in poultry diets should not exceed $15-20 \%$ to prevent metabolic disorders caused by glucosinolates and not to compromise the growth performance of birds [6,7].

Previous research shows that fermentation can improve the nutritional value of diets by increasing protein availability and reducing the content of undesirable compounds in feed ingredients [7-9]. According to Rozan et al. [10], fermentation contributes to the degradation of $84 \%$ of carbohydrates, $30 \%$ of lignin, and $47 \%$ of total glucosinolates in rapeseed meal. Fermented feed components are usually characterized by higher counts of lactic acid bacteria, higher concentrations of selected volatile fatty acids, and a lower $\mathrm{pH}$ compared with raw materials, which can inhibit the growth of bacteria such as Salmonella Typhimurium and Escherichia coli in chickens [11]. Fermented feeds also contribute to increasing the abundance of beneficial microorganisms that exert probiotic effects in the gastrointestinal tract (GIT) [12]. Lactic acid and other short-chain fatty acids (SCFAs) are also produced by the indigenous microflora in the GIT, and are believed to play a role in reducing the numbers of many pathogens [13]. Lactic acid and acetic acid act synergistically against yeasts, molds and bacteria such as Clostridium and Salmonella. Propionic acid and butyric acid are also known as inhibitors of Salmonella growth [14]. Therefore, SCFAs, the major end products of fermentation, stabilize gut microbial composition and function, and constitute an additional energy source that can slightly improve the growth performance of birds [4].

The intestinal microbiota has recently been shown to largely affect host health and growth parameters through various functional roles in terms of nutrition and physiological metabolism [15]. Microbial diversity exerts a considerable effect on fermentation processes in the GIT. In poultry, the GIT harbors a very diverse microbial population, with over 600 different bacterial species representing more than 100 bacterial genera [16]. Unfortunately, the relevant data for turkeys are scarce, although the GIT is assumed to play a critical role in overall health in poultry.

The results of previous studies revealed that fermented raw material may have a positive influence on the gut ecosystem and morphology, immune function, and growth performance of birds [17]. However, the effect of fermentation of rapeseed products on gut function in turkeys remains insufficiently investigated. In view of the above, the objective of this study was to determine the effect of raw and fermented rapeseed cake on the physiological response of the GIT in turkey.

\section{Materials and Methods}

The study protocol was approved by the Local Ethics Committee for Animal Experiments in Olsztyn, Poland (decision number 30/2015). The animals were maintained accordingly to the guidelines comparable to EU Directive 2010/63/EU [18].

\subsection{Rapeseed Cake}

Rapeseed cake was purchased on the domestic market, from the Bielmar Fat and Oil Processing Plant in Bielsko-Biała, Poland. The raw material was ground and thoroughly mixed with water in a ratio of 1:2 in plastic containers. Rapeseed cake was fermented with the use of a commercial enzyme preparation of 6-phytase expressed in Pichia pastoris. The substrate was inoculated with enzymes $\left(0.1 \%\right.$ on a RC weight basis) and mixed. Solid-state fermentation was conducted for $24 \mathrm{~h}$ at $30^{\circ} \mathrm{C}$ under anaerobic conditions. The enzymes were deactivated at $70^{\circ} \mathrm{C}$ within $15 \mathrm{~min}$, and the fermented biomass was dried at $55^{\circ} \mathrm{C}$. The fermentation process was carried out under patent-pending procedure No. 422849. 


\subsection{Animals and Experimental Design}

The experimental material consisted of one-day-old female Hybrid Converter turkeys raised until 112 days of age. Turkeys were raised in pens on litter in a building with a controlled environment. Every pen was equipped with an automatic feeder and a bell-type drinker, and both water and feed were provided ad libitum. The temperature and lighting programs were consistent with the recommendations of Hybrid Turkeys [19].

The experiment was carried out on 1350 turkeys assigned to three experimental groups of 450 birds each (9 replications of 50 individuals each), which differed in the source of feed protein. In the control group, soybean meal was the main source of dietary protein, whereas the experimental groups were fed diets containing 15\% of RRC or FRC. All diets were isocaloric and isonitrogenous, and contained similar amounts of major amino acids (including lysine, methionine with cysteine and threonine), minerals (including calcium and available phosphorus), and vitamins. The nutritional value of diets was consistent with the nutrient requirements of turkeys [19]. The compositions of control and experimental diets prepared in successive 4-week feeding periods are shown in Table 1.

Table 1. Composition and calculated analysis of control (C) and experimental diets containing raw rapeseed cake (RRC) or fermented rapeseed cake (FRC) fed during four feeding periods to turkeys aged 1-112 days, in $\mathrm{g} / \mathrm{kg}$ as-fed basis (unless indicated otherwise).

\begin{tabular}{|c|c|c|c|c|c|c|c|c|c|c|c|c|}
\hline \multirow{2}{*}{ Compounds } & \multicolumn{3}{|c|}{ Weeks 1 to 4} & \multicolumn{3}{|c|}{ Weeks 5 to 8} & \multicolumn{3}{|c|}{ Weeks 9 to 12} & \multicolumn{3}{|c|}{ Weeks 13 to 16} \\
\hline & C & RRC & FRC & $\mathrm{C}$ & RRC & FRC & C & RRC & FRC & $\mathrm{C}$ & RRC & FRC \\
\hline Wheat & 519.4 & 429.3 & 429.3 & 522.2 & 434.6 & 434.6 & 627.3 & 539.7 & 539.7 & 721.4 & 633.7 & 633.7 \\
\hline Soybean meal & 414.8 & 345.5 & 345.5 & 388.5 & 318 & 318 & 282.4 & 211.9 & 211.9 & 201 & 130.5 & 130.5 \\
\hline Rapeseed cake & - & 150.0 & - & - & 150.0 & - & - & 150.0 & - & - & 150.0 & - \\
\hline Fermented rapeseed cake & - & - & 150.0 & - & - & 150.0 & - & - & 150.0 & - & - & 150.0 \\
\hline Soybean oil & 16.6 & 28.3 & 28.3 & 40.9 & 52.1 & 52.1 & 49.5 & 60.8 & 60.8 & 47.4 & 58.7 & 58.7 \\
\hline Monocalcium phosphate & 17.8 & 17 & 17 & 15.5 & 15 & 15 & 11.4 & 10.9 & 10.9 & 7 & 6.5 & 6.5 \\
\hline Sodium bicarbonate & 1.9 & 1.9 & 1.9 & 1.5 & 1.5 & 1.5 & 1.5 & 1.5 & 1.5 & 1.5 & 1.5 & 1.5 \\
\hline Sodium chloride & 2 & 1.8 & 1.8 & 1.8 & 1.8 & 1.8 & 1.6 & 1.6 & 1.6 & 1.2 & 1.2 & 1.2 \\
\hline Limestone & 15.2 & 14 & 14 & 16.8 & 15.3 & 15.3 & 14.3 & 12.8 & 12.8 & 10.3 & 8.8 & 8.8 \\
\hline Choline chloride & 0.9 & 0.9 & 0.9 & 1 & 1 & 1 & 1 & 1 & 1 & 1 & 1 & 1 \\
\hline L-Lysine HCL & 4.3 & 4.7 & 4.7 & 4.6 & 4.6 & 4.6 & 4.6 & 4.5 & 4.5 & 3.7 & 3.6 & 3.6 \\
\hline DL-Methionine & 3.3 & 2.9 & 2.9 & 3 & 2.4 & 2.4 & 2.3 & 1.7 & 1.7 & 1.9 & 1.3 & 1.3 \\
\hline L-Threonine & 1.1 & 1 & 1 & 1.3 & 0.9 & 0.9 & 1.3 & 0.9 & 0.9 & 0.9 & 0.5 & 0.5 \\
\hline Enzymes & 0.3 & 0.3 & 0.3 & 0.3 & 0.3 & 0.3 & 0.3 & 0.3 & 0.3 & 0.3 & 0.3 & 0.3 \\
\hline Vitamin-mineral premix ${ }^{1}$ & 2.5 & 2.5 & 2.5 & 2.5 & 2.5 & 2.5 & 2.5 & 2.5 & 2.5 & 2.5 & 2.5 & 2.5 \\
\hline \multicolumn{13}{|c|}{ Analyzed nutrients } \\
\hline Crude protein & 271 & 277 & 277 & 258 & 255 & 255 & 220 & 226 & 226 & 184 & 186 & 186 \\
\hline Crude fat & 40.5 & 59 & 59 & 52.6 & 75.6 & 75.6 & 54.3 & 69.9 & 69.9 & 60.3 & 75.1 & 75.1 \\
\hline \multicolumn{13}{|c|}{ Calculated nutritional value ${ }^{2}$} \\
\hline $\mathrm{ME}, \mathrm{kcal} / \mathrm{kg}$ & 2750 & 2750 & 2750 & 2900 & 2900 & 2900 & 3050 & 3050 & 3050 & 3125 & 3125 & 3125 \\
\hline Crude fiber & 26.9 & 45.5 & 45.5 & 28.2 & 46.5 & 46.5 & 26.7 & 45 & 45 & 25.9 & 44.2 & 44.2 \\
\hline Lysine & 17.4 & 17.4 & 17.4 & 16.3 & 16.3 & 16.3 & 13.6 & 13.6 & 13.6 & 10.9 & 10.9 & 10.9 \\
\hline Arginine & 17.4 & 17.4 & 17.4 & 15.8 & 15.6 & 15.6 & 12.8 & 12.6 & 12.6 & 10.5 & 10.4 & 10.4 \\
\hline Methionine & 6.8 & 6.7 & 6.7 & 6.4 & 6 & 6 & 5.2 & 4.8 & 4.8 & 4.4 & 4.1 & 4.1 \\
\hline Methionine + Cysteine & 11.3 & 11.3 & 11.3 & 10.5 & 10.5 & 10.5 & 8.8 & 8.8 & 8.8 & 7.7 & 7.7 & 7.7 \\
\hline Threonine & 10.4 & 10.4 & 10.4 & 10 & 10 & 10 & 8.4 & 8.4 & 8.4 & 6.8 & 6.8 & 6.8 \\
\hline Tryptophan & 3.4 & 3.4 & 3.4 & 3.1 & 3.1 & 3.1 & 2.6 & 2.6 & 2.6 & 2.2 & 2.3 & 2.3 \\
\hline $\mathrm{Ca}$ & 13 & 13 & 13 & 11 & 11 & 11 & 9 & 9 & 9 & 6.5 & 6.5 & 6.5 \\
\hline Available P & 7 & 7 & 7 & 5 & 5 & 5 & 4 & 4 & 4 & 3 & 3 & 3 \\
\hline
\end{tabular}

${ }^{1}$ provided the following per kilogram of diet in weeks 1-8 and 9-16: vitamin A, 12,500 and 9600 IU; vitamin D3, 5000 and $4800 \mathrm{IU}$; vitamin E, 100 and $60 \mathrm{mg}$; vitamin $\mathrm{K} 3,4$ and $3 \mathrm{mg}$; vitamin B1, 4.5 and $2 \mathrm{mg}$; vitamin B2, 15 and $12 \mathrm{mg}$; vitamin B6, 5 and $5 \mathrm{mg}$; vitamin B12, 16 and $0.03 \mathrm{mg}$; folic acid, 3 and $2.5 \mathrm{mg}$; pantothenic acid, 28 and $23 \mathrm{mg}$, nicotinic acid, 110 and $85 \mathrm{mg}$; biotin, 0.38 and $0.38 \mathrm{mg}$; Mn, 160 and $120 \mathrm{mg} ; \mathrm{Zn}, 160$ and $120 \mathrm{mg}$; Fe, 80 and $40 \mathrm{mg}$; $\mathrm{Cu}, 25$ and $25 \mathrm{mg}$; I, 2.5 and $2 \mathrm{mg}$; Se, 0.3 and $0.3 \mathrm{mg}$, respectively ${ }^{2}$ Calculated according to Polish Feedstuff Analysis Tables [20]. 
The diets for the first period (days 1 to 28) were offered in crumble form, and the diets offered in the subsequent periods (days 29-112) were fed in pelleted form. At the end of each 4-week period, the body weight (BW) of turkeys, feed intake (FI) and mortality rates were recorded, and each pen of 50 birds was considered as an experimental unit. Feed conversion ratio (FCR) was calculated for each group based on BW gain and feed consumption.

\subsection{Sample Collection}

After 112 days of feeding, nine birds representing the average BW of each group were slaughtered by cervical dislocation to collect the test material. The ceacums were removed, emptied, and digesta was homogenized. Subsequently, samples were collected and used for the analysis of SCFAs and bacterial enzymes activity. The remaining portion of cecal digesta was transferred to test tubes and stored at $-70{ }^{\circ} \mathrm{C}$ until needed.

\subsection{Chemical Analysis}

For chemical analyses, samples of RC were ground to pass through a 0.5-mm sieve. The samples were analyzed in duplicate for the content of DM, CP, and crude fiber (CF) according to AOAC [21] methods 934.01, 976.05 and 978.10, respectively. Gross energy (GE) was determined with an adiabatic bomb calorimeter (KL 12 Mn, Precyzja-Bit PPHU, Poland) standardized with benzoic acid. Phytate-phosphorus was determined as described by Haugh and Lantzsch [22]. Non-starch polysaccharides (NSP) were determined by gas-liquid chromatography (constituent neutral sugars) using an SP-2340 column and a Varian CP3380 gas chromatograph (Varian Inc., Palo Alto, CA, USA), and by colorimetry (uronic acids) using a Biochrom Ultrospec 50 (Biochrom Ltd., Cambridge, UK), according to the procedure described by Englyst and Cummings $(1984,1988)$ with modifications [23]. Uronic acids were determined as described by Scott [24]. Sugars (glucose-GLU, fructose, sucrose, raffinose, and stachyose) were determined as described by Slominski et al. [25]. Glucosinolates were determined by gas-liquid chromatography as described by Slominski and Campbell [26].

SCFAs were analyzed by gas chromatography (Shimadzu GC-2010, Kyoto, Japan) equipped with a capillary column (SGE, BP21, $30 \mathrm{~m} \times 0.53 \mathrm{~mm}$, SGE Europe Ltd., Kiln Farm Milton Keynes, UK). Samples of digesta $(0.2 \mathrm{~g})$ were mixed with $0.2 \mathrm{~mL}$ of formic acid, diluted with deionized water and centrifuged at $7211 \mathrm{~g}$ for $10 \mathrm{~min}$. The supernatant was loaded onto a capillary column (SGEBP21, $30 \mathrm{~m} \times 0.53 \mathrm{~mm}$ ) using an on-column injector.

The activities of bacterial enzymes ( $\alpha$-and $\beta$-glucosidase, $\alpha$-and $\beta$-galactosidase, $\beta$-glucuronidase, $\alpha$-arabinopyranosidase, $\alpha$-arabinofuranosidase $\beta$-xylosidase, $\beta$-cellobiosidase) released into the cecal environment were measured as the rate of $\mathrm{p}$ - or o-nitrophenol release from their respective nitrophenylglucosides [27]. The reaction mixture contained $0.3 \mathrm{~mL}$ of a substrate solution (5 mM) and $0.2 \mathrm{~mL}$ of a 1:10 (v/v) dilution of the cecal digesta sample in $100 \mathrm{mM}$ phosphate buffer (pH 7.0) after centrifugation at $7211 \mathrm{~g}$ for $15 \mathrm{~min}$. Incubation was carried out at $39{ }^{\circ} \mathrm{C}$, and p-nitrophenol was quantified at $400 \mathrm{~nm}$ and at $420 \mathrm{~nm}$ (o-nitrophenol concentration) after the addition of $2.5 \mathrm{~mL}$ of $0.25 \mathrm{M}$ cold sodium carbonate. Enzyme activity was expressed as $\mu \mathrm{mol}$ of the product formed per $\mathrm{h}$ per $\mathrm{g}$ of digesta.

\subsection{Bacterial DNA Eextraction and 16SrRNA Sequencing}

DNA was extracted from the cecal digesta with a commercial kit (Sherlock AX, A\&A Biotechnology, Poland) according to the manufacturer's instructions. The samples were mechanically lysed on FastPrep-24 on Zirconia beads (A\&A Biotechnology, Poland) followed by additional lysis with enzymatic mix. The presence of bacterial DNA in the samples was confirmed using Real-Time PCR on the Mx3000P thermocycler (Stratagene, La Jolla, CA, USA) using SYBR Green as fluorochrome. Universal reaction primers, 1055F 5'-ATGGCTGTCGTCAGCT-3' and 1392R 5'-ACGGGCGGTGTGTAC-3', were used for the amplification of $16 \mathrm{~S}$ rDNA. The temperature profile of the reaction was as follow: $95{ }^{\circ} \mathrm{C}, 3 \mathrm{~min} ; 95{ }^{\circ} \mathrm{C}, 15 \mathrm{~s} ; 58{ }^{\circ} \mathrm{C}, 30 \mathrm{~s} ; 72{ }^{\circ} \mathrm{C}, 30 \mathrm{~s}$; $\mathrm{Tm} 65{ }^{\circ} \mathrm{C}->95{ }^{\circ} \mathrm{C}$. DNA was quantified 
using the NanoDrop (NanoDrop Technologies, Wilmington, DE, USA) and standardized at a final concentration of $5 \mathrm{ng} / \mu \mathrm{L}$. Microbial diversity was determined by sequencing the amplified V3-V4 region of the 16S rRNA gene with the use of the following primers: 16S Amplicon PCR Forward Primer 5'TCGTCGGCAGCGTCAGATGTGTATAAGAGACAGCCTACGGGNGGCWGCG 16S Amplicon PCR Reverse Primer 5'GTCTCGTGGGCTCGGAGATGTGTATAAGAGACAGGACTACHVGGGTATCTAATC.

The following PCR conditions were applied: $95^{\circ} \mathrm{C}$ for $3 \mathrm{~min} ; 25$ cycles of $95^{\circ} \mathrm{C}$ for $30 \mathrm{~s}, 55^{\circ} \mathrm{C}$ for $30 \mathrm{~s}, 72{ }^{\circ} \mathrm{C}$ for $30 \mathrm{~s}, 72{ }^{\circ} \mathrm{C}$ for $5 \mathrm{~min}$, hold at $4{ }^{\circ} \mathrm{C}$. The expected product size on a Bioanalyzer trace after the Amplicon PCR step was $\sim 550 \mathrm{bp}$. The PCR products were cleaned up using AMPure $\mathrm{XP}$ beads. The libraries were sequenced running $2 \times 250 \mathrm{bp}$ paired-end reads. The PCR products were cleaned and the library was combined with the sequencing adapters and dual indices using the Nextera XT Index Kit (Illumina, San Diego, CA, USA) according to the $16 \mathrm{~S}$ metagenomic sequencing library preparation instruction (Illumina, San Diego, CA, USA). The PCR with Nextera XT Index Primers was carried out under the following conditions: $95^{\circ} \mathrm{C}$ for $3 \mathrm{~min} ; 8$ cycles of $95^{\circ} \mathrm{C}$ for $30 \mathrm{~s}$, $55{ }^{\circ} \mathrm{C}$ for $30 \mathrm{~s}, 72{ }^{\circ} \mathrm{C}$ for $30 \mathrm{~s}, 72{ }^{\circ} \mathrm{C}$ for $5 \mathrm{~min}$, hold at $4{ }^{\circ} \mathrm{C}$. The PCR products were cleaned up again with AMPure XP beads. The final library was validated to the expected size on a Bioanalyzer trace of $\sim 630 \mathrm{bp}$. The libraries were quantified using a fluorometric quantification method and dsDNA binding dyes. The individual concentrations of DNA libraries were calculate in $\mathrm{nM}$, based on the size of DNA amplicons as determined by the Agilent Technologies 2100 Bioanalyzer.

For sequencing the individual libraries, they were diluted to $4 \mathrm{nM}$, denatured with $10 \mathrm{mM}$ Tris pH 8.5 and spiked with $20 \%(\mathrm{v} / \mathrm{v})$ of PhiX. An aliquot of $5 \mu \mathrm{L}$ of diluted DNA was mixed to prepare pooled libraries for the MiSeq (Illumina, San Diego, CA, USA) run. > 100,000 reads were performed per sample. The sequencing data were clustered into operational taxonomic units (OTUs), and were classified at several taxonomic levels, kingdom, phylum, class, order, family, genus and species. The Greengenes database was used for metagenomic analysis.

\subsection{Statistical Analysis}

For a statistical analysis of performance parameters, a single pen $(n=9)$ was considered as a replicate experimental unit. For analyses of the physiological and microbiological parameters of the GIT, individual birds were considered as experimental units. All analyses were performed on 27 birds representing 9 replicates from each of the 3 experimental groups. One-way analysis of variance (ANOVA) was performed with the use of Statistica 10.0 software (StatSoft, Krakow, Poland). When a significant treatment effect was noted, the post-hoc Tukey test was used to determine differences between treatment groups. Data were presented as means \pm SEM, and the value of $p<0.05$ was considered statistically significant. The post-hoc Tukey HSD test did not reveal significant differences between group means with regard to the BW of birds and butyric acid, although $p$-value reached 0.04. Therefore, Duncan's test was used, and the observed significant differences were considered as tendencies. The significance of differences between livability data was determined by the Kruskal-Wallis test by ranks (non-parametric ANOVA on ranks).

\section{Results}

Fermentation increased the content of $\mathrm{DM}, \mathrm{CP}$, and CF, and decreased the content of anti-nutritional factors in RC (Table 2). In comparison with RRC, FRC had nearly ten-fold lower glucosinolates content, nearly two-fold lower carbohydrates content and nearly twenty-fold lower content of phytate-phosphorus. Fermentation had no effect on NSP concentrations in RC. 
Table 2. Chemical composition of raw rapeseed cake (RRC) and fermented rapeseed cake (FRC) $(\mathrm{g} / \mathrm{kg}$, dry matter basis).

\begin{tabular}{ccc}
\hline Component & RRC & FRC \\
\hline Dry matter & 912 & 935 \\
Crude protein & 325 & 349 \\
Crude fiber & 155 & 164 \\
Gross energy (kcal/kg) & 5127 & 5240 \\
Phytate-phosphorus $_{\text {NSP }}^{1}$ & 3.07 & 0.16 \\
Glucosinolates $^{2}(\mu \mathrm{mol} / \mathrm{g})$ & 222 & 226 \\
Sugars $^{3}$ & 16.3 & 1.66 \\
\hline
\end{tabular}

${ }^{1}$ non-starch polysaccharides including rhamnose, arabinose, xylose, mannose, galactose, glucose, uronic acids; ${ }^{2}$ including gluconapin, glucobrassicinapin, progoitrin, glucobrassicin, hydroxyglucobrassicin; ${ }^{3}$ including glucose, fructose, sucrose, raffinose, and stachyose.

\subsection{Effect of Diets Containing RRC or FRC on Growth Performance.}

The inclusion of $15 \%$ of RRC or FRC in turkey diets had no influence on the growth performance parameters of birds, including DFI, FCR, and livability (Table 3). However, the average final BW of turkeys receiving RRC tended to decrease in comparison with the remaining groups. Fermentation increased the final BW of turkeys, which was approximately $1.3 \%$ higher in the FRC group than in the RRC group, and comparable with that in the control group $(p=0.043)$.

Table 3. Growth performance of turkeys fed a control diet $(\mathrm{C})$ and diets containing raw rapeseed cake (RRC) or fermented rapeseed cake (FRC).

\begin{tabular}{cccccc}
\hline \multirow{2}{*}{ Item } & \multicolumn{3}{c}{ Dietary Treatment } & \multirow{2}{*}{ SEM } & $p$-Value \\
\cline { 2 - 4 } & $\mathbf{C}$ & RRC & FRC & & \\
\hline DFI, g & 258 & 256 & 261 & 1.372 & 0.336 \\
BW, $\mathrm{kg}$ & $10.82^{\mathrm{x}}$ & $10.68^{\mathrm{y}}$ & $10.83^{\mathrm{x}}$ & 0.027 & 0.043 \\
$\mathrm{FCR}, \mathrm{kg} / \mathrm{kg}$ & 2.53 & 2.51 & 2.52 & 0.010 & 0.819 \\
Livability, \% & 99.1 & 99.8 & 97.6 & 0.381 & 0.165 \\
\hline
\end{tabular}

$\mathrm{x}, \mathrm{y}$ means within a row with different superscripts were considered as a near-significant trend; DFI—daily feed intake; BW—body weight; FCR—feed conversion ratio.

\subsection{Effect of Diets Containing RRC or FRC on SCFA Concentrations and the Activities of Bacterial Enzymes in the Cecal Digesta}

The inclusion of RRC or FRC in turkey diets slightly affected SCFA concentrations in the cecal digesta (Table 4). Neither total SCFA concentrations nor the total pool or the total concentrations of putrefactive SCFAs differed between the treatments $(p>0.05)$. In the SCFA profile, acetic acid predominated, followed by butyric acid and propionic acid. The proportion of butyric acid in the SCFA profile was higher in birds fed FRC than in those fed RRC ( $p=0.047)$. The concentrations of propionic acid and valeric acid were higher in FRC-fed birds compared with the control treatment $(p=0.028$ and $p=0.048$, respectively).

An analysis of the activities of bacterial enzymes in the cecal digesta (Table 4) indicated that only $\alpha$-glucosidase and $\beta$-galactosidase were not affected by the dietary treatments $(p>0.05)$. More specifically, the activities of $\beta$-glucosidase $(p=0.026), \alpha$-galactosidase $(p=0.024), \alpha$-arabinopyranosidase $(p<0.001), \alpha$-arabinofuranosidase $(p<0.001), \beta$-xylosidase $(p<0.001)$, and $\beta$-celobiosidase $(p<0.001)$ were lower in birds fed diets with FRC vs. RRC. In comparison with the control treatment, the administration of RRC or FRC resulted in lower activity of $\beta$-glucuronidase in the cecal digesta $(p<0.001)$. 
Table 4. Concentrations of short-chain fatty acids (SCFAs) and activities of selected bacterial enzymes in the cecal digesta of turkeys fed a control diet (C) and diets containing raw rapeseed cake (RRC) or fermented rapeseed cake (FRC) from 1 to 112 days of age ${ }^{1}$.

\begin{tabular}{|c|c|c|c|c|c|}
\hline \multirow{2}{*}{ Item } & \multicolumn{3}{|c|}{ Dietary Treatment } & \multirow{2}{*}{ SEM } & \multirow{2}{*}{$p$-Value } \\
\hline & $\mathrm{C}$ & RRC & FRC & & \\
\hline \multicolumn{6}{|c|}{ SCFA concentrations $(\mu \mathrm{mol} / \mathrm{g})$} \\
\hline Acetic acid & 96.4 & 100 & 98.3 & 2.129 & 0.763 \\
\hline Propionic acid & $7.44^{b}$ & $8.70^{\mathrm{ab}}$ & $11.2^{\mathrm{a}}$ & 0.599 & 0.028 \\
\hline Iso-butyric acid & 0.949 & 1.07 & 1.02 & 0.055 & 0.671 \\
\hline Butyric acid & 21.4 & 21.4 & 26.6 & 1.103 & 0.082 \\
\hline Iso-valeric acid & 1.28 & 1.31 & 1.41 & 0.065 & 0.723 \\
\hline Valeric acid & $1.37^{b}$ & $1.65^{\mathrm{ab}}$ & $2.00^{\mathrm{a}}$ & 0.106 & 0.048 \\
\hline Total SCFAs & 129 & 134 & 141 & 3.235 & 0.351 \\
\hline \multicolumn{6}{|c|}{ SCFA profile (\% of total SCFAs) } \\
\hline Acetic acid & $74.8^{\mathrm{a}}$ & $74.7^{\mathrm{a}}$ & $70.2^{b}$ & 0.678 & 0.003 \\
\hline Propionic acid & 5.88 & 6.45 & 7.8 & 0.362 & 0.08 \\
\hline Butyric acid & $16.4^{x y}$ & $15.8^{y}$ & $18.8^{x}$ & 0.536 & 0.047 \\
\hline Total pool of SCFAs ( $\mu \mathrm{mol} / \mathrm{kg}$ BW) & 360.0 & 333.0 & 451.0 & 28.40 & 0.215 \\
\hline Total putrefactive SCFAs & 3.60 & 4.03 & 4.43 & 0.151 & 0.079 \\
\hline \multicolumn{6}{|c|}{ Enzyme activity $(\mathrm{U} / \mathrm{g})$} \\
\hline$\alpha$-glucosidase & 28.6 & 23.2 & 31.5 & 1.759 & 0.154 \\
\hline$\beta$-glucosidase & $1.32^{\mathrm{ab}}$ & $1.39^{\mathrm{a}}$ & $0.933^{\mathrm{b}}$ & 0.076 & 0.026 \\
\hline$\alpha$-galactosidase & $14.6^{\mathrm{ab}}$ & $19.6^{\mathrm{a}}$ & $12.8^{\mathrm{b}}$ & 1.093 & 0.024 \\
\hline$\beta$-galactosidase & 33.2 & 32.6 & 27.4 & 1.344 & 0.161 \\
\hline$\beta$-glucuronidase & $35.5^{\mathrm{a}}$ & $17.4^{\mathrm{b}}$ & $8.23^{b}$ & 2.937 & 0.001 \\
\hline$\alpha$-arabinopyranosidase & $2.04^{\mathrm{a}}$ & $2.36^{\mathrm{a}}$ & $1.32^{b}$ & 0.130 & 0.001 \\
\hline$\alpha$-arabinofuranosidase & $3.71^{\mathrm{a}}$ & $4.64^{\mathrm{a}}$ & $1.95^{b}$ & 0.284 & 0.001 \\
\hline$\beta$-xylosidase & $4.47^{b}$ & $13.1^{\mathrm{a}}$ & $3.75^{b}$ & 1.166 & 0.001 \\
\hline$\beta$-celobiosidase & $1.75^{b}$ & $2.65^{\mathrm{a}}$ & $1.37^{\mathrm{b}}$ & 0.140 & 0.001 \\
\hline
\end{tabular}

1 data representing mean values of 9 birds per treatment; ${ }^{a, b}$ means within a row with different superscripts differ significantly $(p \leq 0.05) ;{ }^{x, y}$ means within a row with different superscripts were considered as a near-significant trend.

\subsection{Effect of Diets Containing RRC or FRC on the Microbial Composition in the Cecal Digesta}

A metagenomic analysis of the cecal digesta revealed that the predominant bacterial phyla were Firmicutes, Bacteroidetes, and Proteobacteria (Table 5). Their relative abundances were as follows: Firmicutes-around 50\% (49.42201003350.33\%), Bacteroidetes-around 20\% (19.15-28.64\%), Proteobacteria-around 5\% (4.68-5.33\%), and Cyanobacteria-around 2.5\% (1.35-3.22\%) of OTUs. Unclassified bacterial 16SrRNA sequences accounted for 6.44 to $7.04 \%$. The inclusion of RRC or FRC in turkey diets did not affect the bacterial populations (OTUs) at the phylum or order levels. The dietary treatments had a minor effect on the relative abundances of bacteria at the family and genus levels. Fermented rapeseed cake caused a significant increase in the relative abundance of Bacteroidaceae ( $p=0.036$ vs. C). The relative abundance of Lactobacillus decreased significantly in the FRC group, and increased in the RRC group ( $p=0.004$ vs. C). 
Table 5. Relative abundance of bacterial communities in the cecal digesta of turkeys fed a control diet (C) and diets containing raw rapeseed cake (RRC) or fermented rapeseed cake (FRC) ${ }^{1}$.

\begin{tabular}{|c|c|c|c|c|c|}
\hline \multirow{2}{*}{ Item } & \multicolumn{3}{|c|}{ Dietary Treatment } & \multirow{2}{*}{ SEM } & \multirow{2}{*}{$p$-Value } \\
\hline & $\mathrm{C}$ & RRC & FRC & & \\
\hline \multicolumn{6}{|c|}{ Phylum } \\
\hline Firmicutes & 50.33 & 60.89 & 49.42 & 9.04 & 0.053 \\
\hline Cyanobacteria & 1.35 & 2.83 & 3.22 & 1.97 & 0.204 \\
\hline Actinobacteria & 10.39 & 4.97 & 5.62 & 5.56 & 0.167 \\
\hline Proteobacteria & 5.33 & 4.68 & 4.73 & 1.62 & 0.711 \\
\hline Bacteroidetes & 24.13 & 19.15 & 28.64 & 9.16 & 0.181 \\
\hline \multicolumn{6}{|c|}{ Order } \\
\hline Lactobacillales & 9.45 & 24.89 & 7.27 & 18.02 & 0.166 \\
\hline Clostridiales & 36.63 & 31.91 & 36.80 & 10.64 & 0.629 \\
\hline Bifidobacteriales & 9.75 & 4.39 & 4.98 & 5.40 & 0.155 \\
\hline Bacteroidales & 16.54 & 12.42 & 20.51 & 6.10 & 0.071 \\
\hline Unclassified & 12.77 & 12.71 & 13.46 & 1.86 & 0.711 \\
\hline Nostocales & 2.13 & 2.55 & 3.36 & 1.72 & 0.649 \\
\hline Sphingobacteriales & 4.97 & 4.87 & 4.85 & 1.90 & 0.993 \\
\hline Flavobacteriales & 1.90 & 2.04 & 2.02 & 0.45 & 0.871 \\
\hline \multicolumn{6}{|c|}{ Family } \\
\hline Clostridiaceae & 15.11 & 13.32 & 13.63 & 6.53 & 0.862 \\
\hline Unclassified & 20.24 & 19.08 & 20.52 & 2.94 & 0.631 \\
\hline Lachnospiraceae & 7.09 & 6.42 & 9.21 & 3.43 & 0.322 \\
\hline Lactobacillaceae & 9.09 & 29.52 & 6.30 & 18.61 & 0.117 \\
\hline Bifidobacteriaceae & 12.66 & 5.19 & 9.33 & 5.88 & 0.188 \\
\hline Ruminococcaceae & 9.49 & 8.70 & 8.88 & 3.59163 & 0.915 \\
\hline Bacteroidaceae & $8.20^{a b}$ & $5.38^{\mathrm{b}}$ & $11.42^{\mathrm{a}}$ & 3.97 & 0.036 \\
\hline Sphingobacteriaceae & 5.77 & 5.76 & 5.43 & 1.22 & 0.909 \\
\hline Rikenellaceae & 6.23 & 6.19 & 5.85 & 1.67 & 0.920 \\
\hline \multicolumn{6}{|c|}{ Genus } \\
\hline Unclassified & 24.65 & 25.31 & 26.26 & 4.26 & 0.780 \\
\hline Lactobacillus & $7.78^{b}$ & $37.31^{\mathrm{a}}$ & $5.95^{b}$ & 11.60 & 0.004 \\
\hline Clostridium & 4.61 & 4.38 & 5.68 & 1.92 & 0.521 \\
\hline Bifidobacterium & 11.97 & 5.12 & 7.42 & 6.62 & 0.333 \\
\hline Blautia & 6.60 & 5.45 & 7.74 & 3.07 & 0.427 \\
\hline Alkaliphilus & 8.68 & 7.55 & 7.71 & 4.79 & 0.899 \\
\hline Faecalibacterium & 7.41 & 6.09 & 6.08 & 3.44 & 0.780 \\
\hline
\end{tabular}

${ }^{1}$ data representing mean values of 9 birds per treatment; ${ }^{a, b}$ means within a row with different superscripts differ significantly $(p \leq 0.05)$.

\section{Discussions}

In the present study, RC fermentation marginally affected its chemical composition, including the content of $\mathrm{CP}, \mathrm{CF}$, and GE. These results corroborate our previous findings [28]. However, the fermentation process decreased the concentrations of anti-nutritional factors and indigestible substances including glucosinolates and phytate phosphorus, which are detrimental to poultry. Therefore, our data indicate that RC fermentation may be beneficial since the predictable value of raw materials after processing is one of the key determinants of their use as feedstuffs in turkey diets.

The present report demonstrated that diets containing $150 \mathrm{~g} / \mathrm{kg}$ of FRC were well utilized by birds, as their growth performance was marginally affected in the experimental groups and remained within the limits typical of female hybrid turkeys of the same age [19]. The fermentation process was beneficial because RRC decreased the final BW of turkeys, relative to the control group, whereas this effect was not observed in birds fed FRC. These data are consistent with the findings of Rad-Spice et al. [29] who noted adverse effects of the dietary inclusion of raw rapeseed in the amount of $150 \mathrm{~g} / \mathrm{kg}$ or higher on the performance of broiler chickens. Therefore, fermentation enables to supplement turkey diets with $\mathrm{RC}$ at $150 \mathrm{~g} / \mathrm{kg}$ without compromising bird performance. 
The nutritional value of different feedstuffs is largely determined by their influence on the physiological status of the gut. In the current study, diets containing either RRC or FRC had a significant effect on cecal parameters, as selected SCFAs concentration and activities of bacterial enzymes. Dietary substrates, including NSP and protein, which are not fully digested and absorbed in the upper GIT of birds, may accumulate in the distal part of the gut, thus altering the profile and activity of microbiota, which manifests as changes in SCFA concentrations. Short-chain fatty acids are an important energy source for the intestinal epithelium, and they can also regulate mucin production and intestinal immune responses, which play a key role in the development of microbiota and in the prevention of pathogen colonization $[13,30]$. In the cecum, which is the main site of fermentation in birds, the digesta is fermented for a longer period of time, and the concentrations of SCFAs are higher than in the ileum. The SCFAs produced in the cecum also play an important role in maintaining bird health [31]. In our study, diets containing RC did not induce excessive fermentation in the cecum since total SCFA concentrations were similar in turkeys fed experimental and control diets. Acetic, butyric and propionic acids are the most abundant SCFAs in the cecal digesta of birds fed different diets. In the current experiment, the above acids were also present in the highest concentrations in the cecal digesta of turkeys, which indicates that experimental diets containing RC did not disturb cecal fermentation [4]. Interestingly, our findings revealed that the replacement of RRC with FRC in turkey diets caused a beneficial shift in the concentration of propionic acid and in the proportion of butyric acid in the SCFA profile. The beneficial metabolic exerted by propionic acid is suggested to increase insulin sensitivity and glucose tolerance as sensed in the portal vein [32], whereas butyric acid is the preferred energy source for enterocytes, it exerts bacteriostatic effects on selected enteric bacteria, and may reduce the abundance of Enterobacteriaceae including Salmonella [14]. Furthermore, butyrate can also affect the hormonal and nervous systems, and therefore affect host physiology, including protection against colorectal cancer, inflammation, and appetite regulation [33]. Branched SCFAs such as isobutyrate and isovalerate are the end-products of protein fermentation, whereas acetic acid, propionic acid, and butyric acid are generated through the fermentation of dietary fibers [34,35]. Thus, in the light of our findings (a minor effect of RC on the SCFA profile and the concentrations of individual fatty acids), the inclusion of RRC and, in particular, FRC in turkey diets did not lead to an excess supply of fermentative protein and fiber substrates. Therefore, $\mathrm{RC}$ is unlikely to cause a negative shift in cecal fermentation. The above results indicate that FRC was well tolerated by birds. The present findings, unlike those reported by Mikulski et al. [6], confirm that rapeseed cultivars have been significantly improved in recent years. Therefore, rapeseed products can be included in turkey diets, especially that additional processing such as fermentation can further improve their nutritional value.

The activities of bacterial enzymes in the cecum are indicative of dietary ingredient-host interactions. The physicochemical structure of the substrates that escaped digestion in the upper GIT affects the activities of bacterial enzymes. In the current study, the use of FRC, but not RRC, downregulated microbial activity in the cecal ecosystem; the activities of most enzymes (in particular $\beta$-glucuronidase, $\alpha$-arabinopyranosidase and $\alpha$-arabinofuranosidase) were lower in birds fed diets with FRC than in those fed the control diet. The decreased activity of $\beta$-glucuronidase may be indicative of reduced E. coli and Clostridium populations, and a lower risk of glucuronide hydrolysis in the gut lumen, which generates toxic and carcinogenic substances from nontoxic glycosides [36]. Similarly, the decreased activities of $\alpha$-arabinopyranosidase, $\alpha$-arabinofuranosidase and $\beta$-xylosidase suggest that there was no shift in the abundance of residing bacteria, which can release arabinose, xylose, arabinose, and galactose from dietary substrates [37].

The microbiome of the intestinal tract plays a fundamental role in gut health by modulating the fermentation of polysaccharides and the metabolism of nitrogen, fatty acids, and lipids. The diversity of gastrointestinal microbiome is believed to have a critical effect on the overall health status of birds. Despite the fact that the interaction between gut microbiota and health status has not been fully elucidated to date, it can be used as a reliable indicator of birds' response to dietary treatment. $16 \mathrm{~S}$ rRNA next-generation sequencing enables to describe all detected microbial populations in one 
analysis. The results of metagenomic bacterial analyses do not depend on bacterial culture conditions and stand in opposition to direct DNA-DNA hybridization methods. The metagenomic data of 16S rRNA sequencing provide important information about the genetic material of the analyzed bacteria. In previous studies [38,39] the bacterial phyla of Firmicutes and Bactroidates were most abundant in the ceca of tukeys, which is consistent with our findings. In the present experiment, the above phyla accounted for $53.5 \%$ and $24.0 \%$, respectively, of the cecal microbiota in turkeys. Moreover, the experimental diets had no significant influence on the relative abundances of the main phyla of bacteria residing in the ceca. However, they significantly affected the abundance of the family Bacteroidaceae in the ceca, which was greater in birds fed FRC than in those fed RRC, whereas the opposite was noted for the genus Lactobacillus. Since the abundance of Bacteroidaceae in birds fed FRC did not differ significantly from that noted in the control birds, their shift should not be attributed to the adverse effect of FRC inclusion. Regarding Lactobacillus bacteria, which are defined as microorganisms exerting a beneficial effect on the host, their significantly lower abundance in turkeys fed FRC than in those fed RRC could be considered undesirable. According the Józefiak et al. [40], an increase in the counts of Bacteroides and a decrease in the counts of Lactobacilli are negatively correlated with intestinal health. However, it should be noted that in the present study, Lactobacillus abundance was similar in turkeys fed FRC and in control birds, thus suggesting that the experimental diets were unlikely to exert an adverse effect on gut microbiota by causing a shift in the abundance of bacteria residing in the cecum. The significantly higher abundance of Lactobacillus in birds fed RRC compared with the remaining treatments, could result from the fact that more substrates escaped digestion in the upper GIT of turkeys and were able to enter their ceca [41], thus supporting Lactobacillus proliferation. This speculation was also supported by the fact that the performance of birds fed FRC was not compromised relative to the RRC group, indicating that the reduction in Lactobacillus abundance in the FRC treatment was marginal in terms of the gut health status. These findings, as well as the responses of SCFAs and bacterial enzymes reported above, appear to confirm that FRC exerted a negligible but generally beneficial effect on gut physiology in turkeys.

\section{Conclusions}

The results of this study indicate that FRC can be included in turkey diets at $150 \mathrm{~g} / \mathrm{kg}$ without compromising the growth performance of turkeys and maintaining a healthy gut. Our findings also suggest that in comparison with unprocessed RC, the fermentation process improved the nutritional value of RC and exerted beneficial effects on SCFA concentrations and the activities of bacterial glycolytic enzymes. Therefore, fermentation represents an interesting approach to increasing the efficacy of RC in commercial turkey nutrition.

Author Contributions: Conceptualization, A.A.D.; Data curation, A.A.D. and A.J.; Formal analysis, A.A.D., J.J. and A.J.; Investigation, J.J. and P.K.; Methodology, A.A.D., J.J. and A.J.; Writing-original draft, A.A.D., A.J. and P.K.; Writing-review and editing, A.A.D. and P.K. All authors have read and agreed to the published version of the manuscript.

Funding: This study was conducted under the Biostrateg program entitled "GUTFEED - innovative nutrition in sustainable poultry production" and supported by the National Centre for Research and Development (Project No. 267659/7/NCBR/2015).

Conflicts of Interest: The authors declare that they have no competing interest.

\section{References}

1. Smulikowska, S.; Czerwiński, J.; Mieczkowska, A. Nutritional value of rapeseed expeller cake for broilers: Effect of dry extrusion. J. Anim. Feed Sci. 2006, 15, 447-455. [CrossRef]

2. Jakobsen, G.V.; Jensen, B.B.; Knudsen, K.E.B.; Canibe, N. Improving the nutritional value of rapeseed cake and wheat dried distillers grains with soluble by addition of enzymes during liquid fermentation. Anim. Feed Sci. Technol. 2015, 208, 198-213. [CrossRef] 
3. Kocher, A.; Choct, M.; Porter, M.D.; Broz, J. The effects of enzyme addition to broiler diets containing high concentrations of canola or sunflower meal. Poult. Sci. 2000, 79, 1767-1774. [CrossRef] [PubMed]

4. Zduńczyk, Z.; Jankowski, J.; Juskiewicz, J.; Mikulski, D.; Slominski, B.A. Effect of different dietary levels of low-glucosinolate rapeseed (canola) meal and non-starch polysaccharide-degrading enzymes on growth performance and gut physiology of growing turkeys. Can. J. Anim. Sci. 2013, 93, 353-362. [CrossRef]

5. Feng, D.; Zuo, J. Nutritional and anti-nutritional composition of rapeseed meal and its utilization as a feed ingredient for animal. In Proceedings of the 12th International Rapeseed Congress, Wuhan, China, 26-30 March 2007; pp. 265-270.

6. Mikulski, D.; Jankowski, J.; Zdunczyk, Z.; Juskiewicz, J.; Slominski, B.A. The effect of different dietary levels of rapeseed meal on growth performance, carcass traits and meat quality in turkeys. Poult. Sci. 2012, 91, 215-223. [CrossRef]

7. Aljubori, A.; Idrus, Z.; Soleimani, A.F.; Abdullah, N.; Boo, L.J. Response of broiler chickens to dietary inclusion of fermented canola meal under heat stress condition. Ital. J. Anim. Sci. 2017, 16, 546-551. [CrossRef]

8. Chiang, L.; Lu, W.Q.; Piao, X.S.; Hu, J.K.; Gong, L.M.; Thacker, P.A. Effects of feeding solid-state fermented rapeseed meal on performance, nutrient digestibility, intestinal ecology and intestinal morphology of broiler chickens. Asian Aust. J. Anim. Sci. 2010, 23, 263-271. [CrossRef]

9. Xu, F.Z.; Zeng, X.G.; Ding, X.L. Effects of replacing soybean meal with fermented rapeseed meal on performance, serum biochemical variables and intestinal morphology of broilers. Asian Aust. J. Anim. Sci. 2012, 25, 1734-1741. [CrossRef]

10. Rozan, P.; Villaume, C.; Bau, H.M. Detoxication of rapeseed meal by Rhizopus Oligosporus sp-T3: A first step towards rapeseed protein concentrate. Int. J. Food Sci. Technol. 1996, 31, 85-90. [CrossRef]

11. Niba, A.T.; Beal, J.D.; Kudi, A.C.; Brooks, P.H. Potential of bacterial fermentation as a biosafe method of improving feeds for pigs and poultry. Afr. J. Biotechnol. 2009, 8, 1758-1767. [CrossRef]

12. Goodarzi Boroojeni, F.; Senz, M.; Kozłowski, K.; Boros, D.; Wisniewska, M.; Rose, D.; Zentek, J. The effects of fermentation and enzymatic treatment of pea on nutrient digestibility and growth performance of broilers. Animal 2017, 11, 1698-1707. [CrossRef] [PubMed]

13. Antonissen, G.; Eeckhaut, V.; Van Driessche, K.; Onrust, L.; Haesebrouck, F.; Ducatelle, R.; Moore, R.J.; Van Immerseel, F. Microbial shifts associated with necrotic enteritis. Avian Pathol. 2016, 45, 308-312. [CrossRef] [PubMed]

14. Onrust, L.; Ducatelle, R.; Van Driessche, K.; De Maesschalck, C.; Vermeulen, K.; Haesebrouck, F.; Eeckhaut, V.; Van Immerseel, F. Steering endogenous butyrate production in the intestinal tract of broilers as a tool to improve gut health. Front. Vet. Sci. 2015, 2, 75. [CrossRef]

15. Kohl, K. Diversity and function of the avian gut microbiota. J. Comp. Physiol. B 2012, 182, 591-602. [CrossRef] [PubMed]

16. Torok, V.A.; Hughes, R.J.; Mikkelsen, L.L.; Perez-Maldonado, R.; Balding, K.; MacAlpine, R.; Percy, N.J.; Ophel-Keller, K. Identification and characterization of potential performance-related gut microbiotas in broiler chickens across various feeding trials. Appl. Environ. Microbiol. 2011, 77, 5868-5878. [CrossRef]

17. Hu, Y.; Wang, Y.; Li, A.; Wang, Z.; Zhang, X.; Yun, T.; Qiu, L.; Yin, Y. Effect of fermented rapeseed meal on antioxidant functions, serum biochemical parameters and intestinal morphology in broilers. Food Agric. Immunol. 2016, 27, 182-193. [CrossRef]

18. OJEU. Directive 2010/63/EU of the European Parliament and of the Council on the protection of animals used for scientific purposes. OJEU 20.10.2010, Series L. Off. J. Eur. Union 2010, 276, 33-79.

19. Hybrid Turkeys, 2013. Converter Performance Goals. Available online: http://www.hybridturkeys.com/en/ hybrid-performance-goals/commercial-body-weight-performance-goals (accessed on 20 November 2013).

20. Smulikowska, S.; Rutkowski, A. (Eds.) Recommended Allowances and Nutritive Value of Feedstuffs. Poultry Feeding Standards (in Polish), 4th ed.; The Kielanowski Institute of Animal Physiology and Nutrition, PAS: Jablonna, Poland, 2005.

21. AOAC. Official Methods of Analysis of AOAC Internationa, 18th ed.; Association of Official Analytical Chemists: Washington, DC, USA, 2007.

22. Haugh, W.; Lantzsh, H.J. Sensitive method for the rapid determination of phytate in cereals and cereal products. J. Sci. Food Agric. 1983, 34, 1423-1426. [CrossRef] 
23. Slominski, B.A.; Campbell, L.D. Non-starch polysaccharides of canola meal: Quantification, digestibility in poultry and potential benefit of dietary enzyme supplementation. J. Sci. Food Agric. 1990, 53, 175-184. [CrossRef]

24. Scott, R.W. Colorimetric determination of hexuronic acids in plant materials. Anal. Chem. 1979, 51, 936-941. [CrossRef]

25. Slominski, B.A.; Guenter, W.; Campbell, L.D. New approach to water-soluble carbohydrate determination as a tool for evaluation of plant cell wall degradation enzymes. J. Agric. Food Chem. 1993, 41, 2304-2308. [CrossRef]

26. Slominski, B.A.; Campbell, L.D. Gas chromatographic determination of indole glucosinolates-a re-examination. J. Sci. Food Agric. 1987, 40, 131-143. [CrossRef]

27. Juśkiewicz, J.; Zduńczyk, Z.; Żary-Sikorska, E.; Król, B.; Milala, J.; Jurgoński, A. Effect of dietary polyphenolic fraction of chicory root, peel, seed and leaf extracts on caecal fermentation and blood parameters in rats fed diets containing prebiotic fructans. Br. J. Nutr. 2011, 105, 710-720. [CrossRef] [PubMed]

28. Drażbo, A.; Ognik, K.; Zaworska, A.; Ferenc, K.; Jankowski, J. The effect of raw and fermented rapeseed cake on the metabolic parameters, immune status, and intestinal morphology of turkeys. Poult. Sci. 2018, 97, 3910-3920. [CrossRef]

29. Rad-Spice, M.; Rogiewicz, A.; Jankowski, J.; Slominski, B.A. Yellow-seeded B. napus and B. juncea canola. Part 1. Nutritive value of the meal for broiler chickens. Anim. Feed Sci. Technol. 2018, 240, 66-77. [CrossRef]

30. Konieczka, P.; Nowicka, K.; Madar, M.; Taciak, M.; Smulikowska, S. Effects of pea extrusion and enzyme and probiotic supplementation on performance, microbiota activity and biofilm formation in the broiler gastrointestinal tract. Br. Poult. Sci. 2018, 59, 654-662. [CrossRef]

31. Rehman, H.U.; Vahjen, W.; Awad, W.A.; Zentek, J. Indigenous bacteria and bacterial metabolic products in the gastrointestinal tract of broiler chickens. Arch. Anim. Nutr. 2007, 61, 319-335. [CrossRef]

32. De Vadder, F.; Plessier, F.; Gautier-Stein, A.; Mithieux, G. Vasoactive intestinal peptide is a local mediator in a gut-brain neural axis activating intestinal gluconeogenesis. Neurogastroenterol. Motil. 2015, 27, 443-448. [CrossRef]

33. Flint, H.J.; Scott, K.P.; Louis, P.; Duncan, S.H. The role of the gut microbiota in nutrition and health. Nat. Rev. Gastroenterol. Hepatol. 2012, 9, 577-589. [CrossRef]

34. Koh, A.; De Vadder, F.; Kovatcheva-Datchary, P.; Bäckhed, F. From dietary fiber to host physiology: Short-chain fatty acids as key bacterial metabolites. Cell 2016, 165, 1332-1345. [CrossRef]

35. Heimann, E.; Nyman, M.; Pålbrink, A.K.; Lindkvist-Petersson, K.; Degerman, E. Branched short-chain fatty acids modulate glucose and lipid metabolism in primary adipocytes. Adipocyte 2016, 5, 359-368. [CrossRef] [PubMed]

36. Beaud, D.; Talliez, P.; Anba-Mondoloni, J. Genetic characterization of the $\beta$-glucuronidase enzyme from a human intestinal bacterium Ruminococcus gnavus. Microbiology 2005, 151, 2323-2330. [CrossRef] [PubMed]

37. Lagaert, S.; Pollet, A.; Courtin, C.M.; Volckaert, G. $\beta$-Xylosidases and $\alpha$-arabinofuranosidases: Accessory enzymes for arabinoxylan degradation. Biotechnol. Adv. 2014, 32, 316-332. [CrossRef] [PubMed]

38. Wilkinson, T.J.; Cowan, A.A.; Vallin, H.E.; Onime, L.A.; Oyama, L.B.; Cameron, S.J.; Gonot, C.; Moorby, J.M.; Waddams, K.; Theobald, V.J.; et al. Characterization of the microbiome along the gastrointestinal tract of growing turkeys. Front. Microbiol. 2017, 8, 1089. [CrossRef]

39. Yadav, S.; Jha, R. Strategies to modulate the intestinal microbiota and their effects on nutrient utilization, performance, and health of poultry. J. Anim. Sci. Biotechnol. 2019, 10, 1-11. [CrossRef] [PubMed]

40. Józefiak, A.; Benzertiha, A.; Kierończyk, B.; Łukomska, A.; Wesołowska, I.; Rawski, M. Improvement of cecal commensal microbiome following the insect additive into chicken diet. Animals 2020, 10, 577. [CrossRef] [PubMed]

41. Konieczka, P.; Smulikowska, S. Viscosity negatively affects the nutritional value of blue lupin seeds for broilers. Animal 2018, 12, 1144-1153. [CrossRef]

(C) 2020 by the authors. Licensee MDPI, Basel, Switzerland. This article is an open access article distributed under the terms and conditions of the Creative Commons Attribution (CC BY) license (http://creativecommons.org/licenses/by/4.0/). 